by Jan Inge Faleide ${ }^{1}$, Filippos Tsikalas ${ }^{1,3}$, Asbjørn Johan Breivik ${ }^{1}$, Rolf Mjelde ${ }^{2}$, Oliver

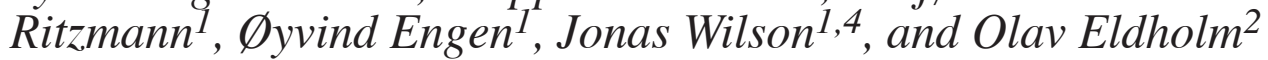

\title{
Structure and evolution of the continental margin off Norway and the Barents Sea
}

\author{
1 Department of Geosciences, University of Oslo, P.O. Box 1047 Blindern, N-0316 Oslo, Norway. E-mail: j.i.faleide@geo.uio.no \\ 2 Department of Earth Science, University of Bergen, Allegaten 41, N-5007 Bergen, Norway. \\ 3 Present address: Eni Norge AS, P.O. Box 101 Forus, N-4064 Stavanger, Norway. \\ 4 Present address: StatoilHydro, N-0246 Oslo, Norway.
}

The Norwegian Margin formed in response to early Cenozoic continental breakup and subsequent opening of the Norwegian-Greenland Sea. There is a welldefined margin segmentation and the various segments are characterized by distinct crustal properties, structural and magmatic styles, and post-opening history of vertical motions. The sedimentary basins at the conjugate continental margins off Norway and Greenland and in the western Barents Sea developed as a result of a series of post-Caledonian rift episodes until early Cenozoic time, when complete continental separation took place.

\section{Introduction}

The Norwegian continental margin comprises the mainly rifted volcanic margin offshore mid-Norway $\left(62-70^{\circ} \mathrm{N}\right)$ and the mainly sheared margin along the western Barents Sea and Svalbard $\left(70-82^{\circ}\right)$ (Figures 1 and 2). Physiographically, the Norwegian margin consists of a continental shelf and slope that vary considerably in width and steepness. The two adjacent shallow seas, the North Sea and the Barents Sea were, prior to the formation of the deep NE Atlantic ocean in early Cenozoic time, part of a much larger epicontinental sea between the continental masses of Fennoscandia, Svalbard and Greenland. The conjugate continental margins off Norway and Greenland (Brekke, 2000; Skogseid et al., 2000; Hamann et al., 2005; Tsikalas et al., 2005a), and the Barents Sea (Faleide et al., 1993; Gudlaugsson et al., 1998), experienced a long history of postCaledonian extension (since Devonian) until breakup in early Cenozoic time. The margins are part of the North Atlantic Volcanic Province (NAVP) (Saunders et al., 1997). The voluminous igneous activity during breakup has left a distinct imprint on the rifted margin segments in terms of extrusive and intrusive magmatism at various crustal levels.

In this paper we synthesize and describe the regional structural and stratigraphic framework of the continental margin off Norway and the Barents Sea, emphasising on margin segmentation, tectonomagmatic style, sediment distribution and possible structural inheritance. The compilation builds on a large amount of integrated seismic reflection, wide-angle refraction and potential field data, and published scientific papers.

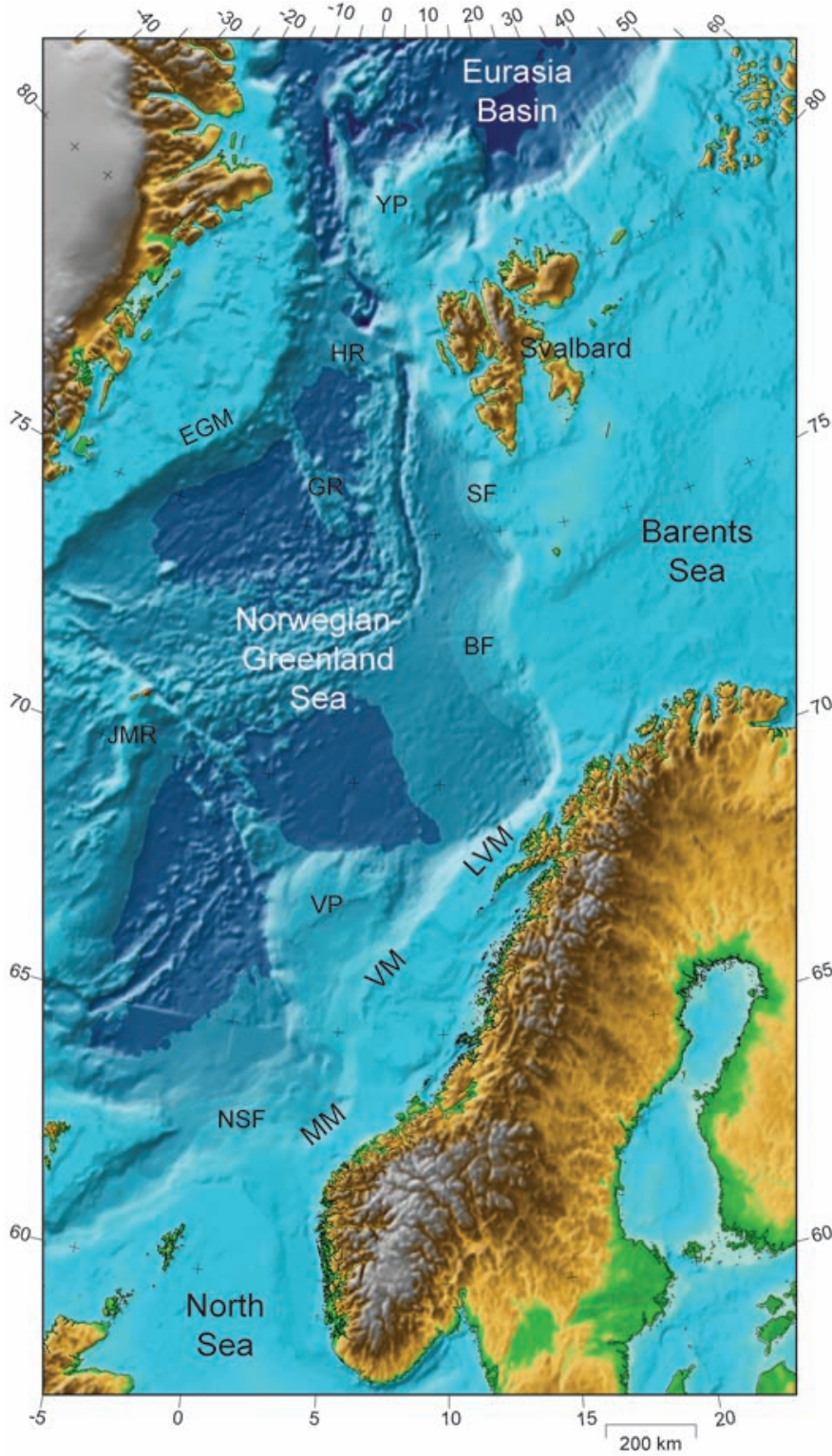

Figure 1 Regional setting of the Norwegian continental margin, which formed in response to the Cenozoic opening of the Norwegian-Greenland Sea. Bathymetry/topography from the $1 \times 1$ ' elevation grid of Jakobsson et al. (2000). BF: Bjornoya Fan, EGM: East Greenland Margin, GR: Greenland Ridge, HR: Hovgård Ridge, JMR: Jan Mayen Ridge, LVM: Lofoten-Vesterålen Margin, MM: Møre Margin, NSF: North Sea Fan, SF: Storfjorden Fan, VM: Vøring Margin, VP: Vøring Plateau, YP: Yermak Plateau. 


\section{Margin structure}

The structural map (Figure 2) and a series of crustal transects (Figures 3 and 4) reveal an along-margin segmentation reflecting different geological provinces. The crustal thickness varies from 4-10 $\mathrm{km}$ in the oceanic Norway and Lofoten basins to about 30-32 km

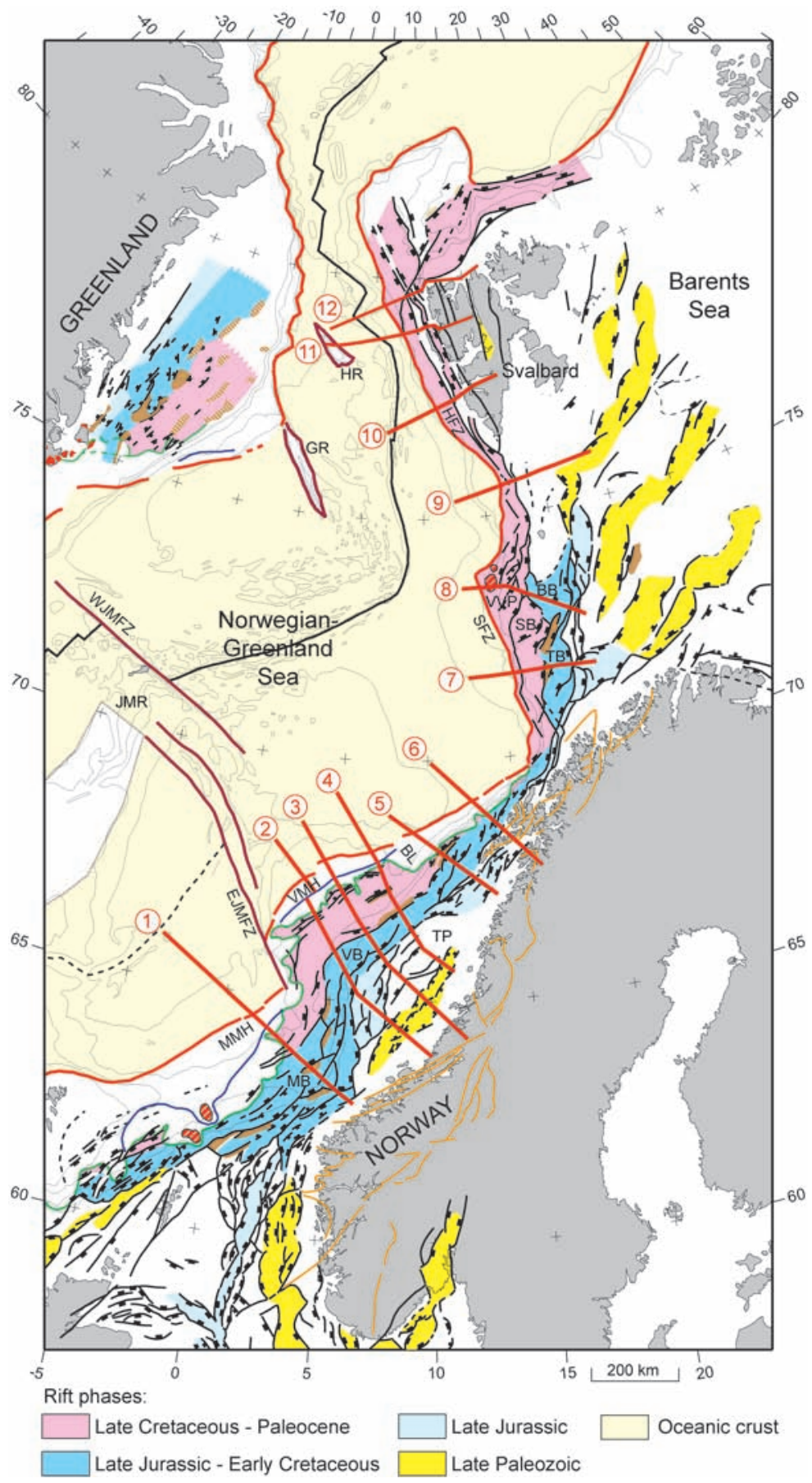

Figure 2 Regional structural map showing structural elements related to different rift phases affecting the NE Atlantic region. Location of margin transects in Figures 3 and 4 also shown. BB: Bjørnøya Basin, BL: Bivrost Lineament, EJMFZ: East Jan Mayen Fracture Zone, GR: Greenland Ridge, HFZ: Hornsund Fault Zone, HR: Hovgård Ridge, JMR: Jan Mayen Ridge, MB: Møre Basin, MMH: Møre Marginal High, SB: Sørvestsnaget Basin, SFZ: Senja Fracture Zone, TB: Tromsø Basin, TP: Trøndelag Platform, VB: Vøring Basin, VMH: Vøring Marginal High, VVP: Vestbakken Volcanic Province, WJMFZ: West Jan Mayen Fracture Zone. near the coastline and in the western Barents Sea, and is primarily governed by multi-phase extensional deformation and breakuprelated magmatism. The transition from oceanic to continental crust differs considerably between the rifted and sheared margin segments.

\section{Mid-Norwegian margin}

The mid-Norwegian margin comprises three main segments (Møre, Vøring and Lofoten-Vesterålen), each between 400-500 km long, separated by the East Jan Mayen Fracture Zone and Bivrost Lineament/transfer zone (Figures 1 and 2). A lower crustal body (LCB) characterized by high P-wave velocities, 7.3-7.6 km/s, believed to be of breakup-related magmatic origin is characteristic for the outer parts of the volcanic margin off mid-Norway (Mjelde et al., 2005a). The LCB is best developed on the Møre and Vøring margin segments where it forms the lower part of the thickened crust beneath the marginal highs, with continuity to the exceptionally thick oceanic crust to the west. To the east, it continues below the crust that was extended and thinned prior to breakup (Figure 3).

The formation of the mid-Norwegian margin comprises the following tectono-magmatic evolution (Eldholm et al., 2002): (1) lithospheric extension during a rift episode in the latest Cretaceous-Paleocene leading to plate breakup and separation, (2) central rift uplift and increased igneous activity during late rifting and a few m.y. after breakup, culminating with voluminous outpourings of basaltic lavas in the Early Eocene, and (3) change to normal accretionary magma volumes with subsequent continental margin subsidence and maturation (Middle Eocene-Present).

The Møre Margin is characterized by a narrow shelf and a wide/gentle slope (Figure 1), underlain by the wide and deep Møre Basin (Figure 2) comprising a thick Cretaceous fill (Figure 3). The inner flank of the Møre Basin is steeply dipping basinward and the crystalline crust thins rapidly from $>25 \mathrm{~km}$ to $<10 \mathrm{~km}$ (Figure 3; profile 1). The sedimentary succession is the thickest along the western part of the basin; $15-16 \mathrm{~km}$, decreasing to $12-13 \mathrm{~km}$ landwards. The deep Møre Basin comprises sub-basins separated by intrabasinal highs formed during Late Jurassic-Early Cretaceous rifting. Most of the structural relief was filled in by mid-Cretaceous time. Sill intrusions are widespread within the Cretaceous succession in central and western parts of the Møre Basin, and lava flows are covering the western part of the basin. A $2-5 \mathrm{~km}$ thick LCB with $>7 \mathrm{~km} / \mathrm{s} \mathrm{P}$-wave velocity is present under most of the Møre Basin. This body has been interpreted as breakup-related magmatic underplating (Olafsson et al., 1992; Raum, 2000). Seaward of the Faeroe-Shetland Escarpment, at the Møre Marginal High (Figures 2 and 3), thickening of the crystalline crust and shallowing of the pre-Cretaceous sediments and top crystalline basement occur near the continent-ocean transition (COT) (Breivik et al., 2006).

The $\sim 500 \mathrm{~km}$ wide Vøring Margin comprises, from southeast to northwest, the Trøndelag Platform, the Halten and Dønna terraces, the Vøring Basin and the Vøring Marginal High (Figures 2 and 3). The Trøndelag Platform has been largely stable since Jurassic time and includes deep basins filled by Triassic and Upper Paleozoic sediments (Figure 3; profiles 2-4). Wide-angle seismic refraction profiles and deep MCS profiles constrain the Moho depth from $\sim 30-32 \mathrm{~km}$ close to mainland Norway to $\sim 25 \mathrm{~km}$ on large parts of the platform. The Vøring Basin can be divided into a series of sub-basins and highs (Figure 3), mainly reflecting differential vertical movements during the Late JurassicEarly Cretaceous basin evolution. Moho is undulating at 20-25 km depth beneath the deep basin (Figure 3; profiles $2-4)$. In most parts of the area the velocity of the lower crust is very high, 7.3-7.6 km/s in a lower crustal body (LCB) created by magmatic underplating (Mjelde et al., 2003, 2005a). 
Alternative interpretations of the LCB, including inherited high pressure granulite/eclogite rocks, melted continental crust or serpentinised mantle rocks, were discussed by Gernigon et al. (2004). The thickness of the body varies considerably laterally within the area, from absence to about $8-9 \mathrm{~km}$. These strong lateral variations might be caused by variations in the pre-breakup structure and/or spatial variations in the magma distribution process.
The Vøring Plateau is a distinct bathymetric feature (Figure 1), and includes the Vøring Marginal High and the Vøring Escarpment (Figures 2 and 3). The Vøring Marginal High consists of an outer part of anomalously thick oceanic crust and a landward part of stretched continental crust covered by thick Early Eocene basalts and underplated by mafic intrusions. Densely spaced OBS data reveal a $25-\mathrm{km}$-wide COT zone beneath the inner parts of seaward
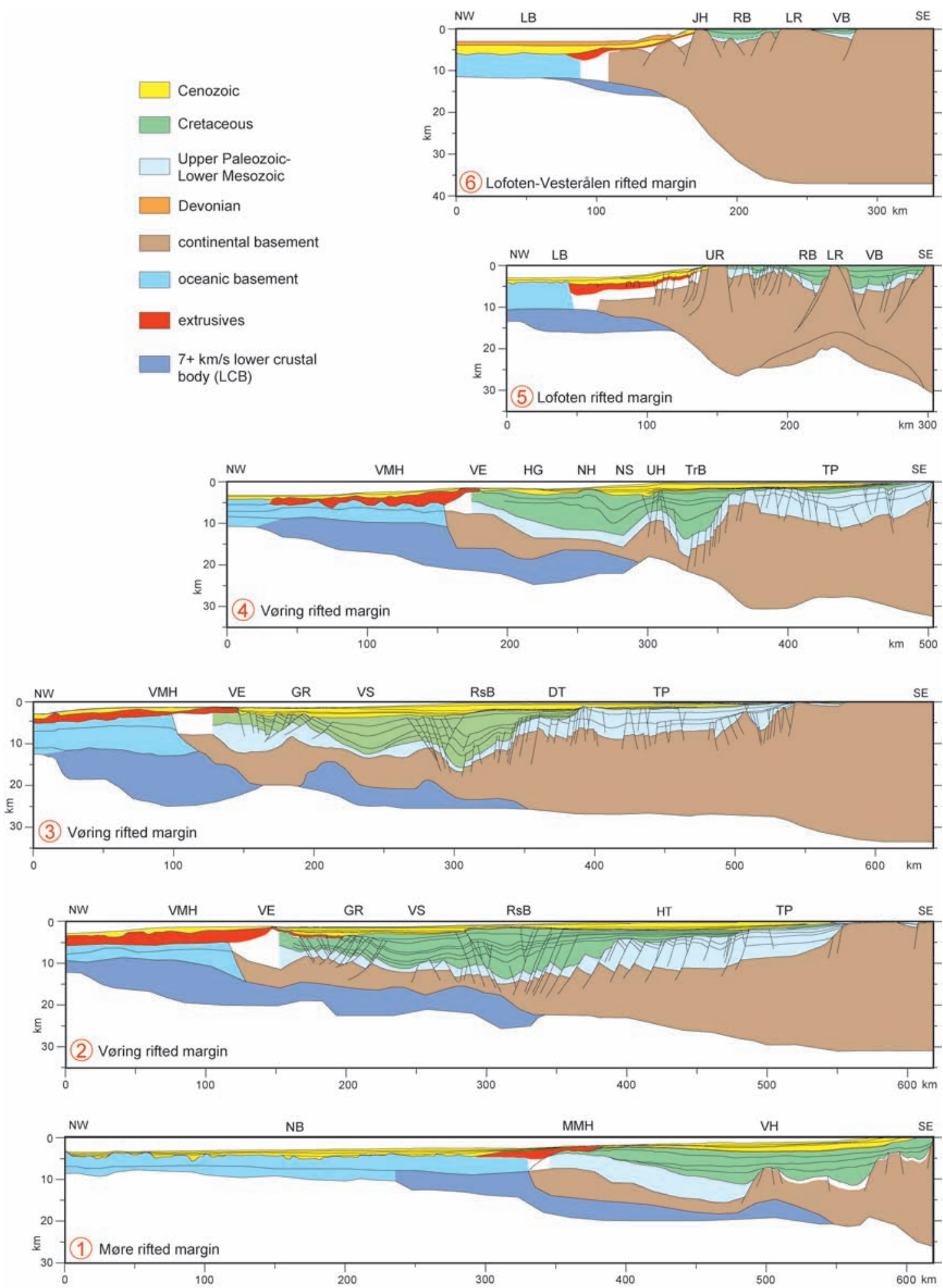

Figure 3 Crustal transects across the rifted continental margin off mid-Norway. Location of profiles in Figure 2. For references see text. DT: Dønna Terrace, GR: Gjallar Ridge, HT: Halten Terrace, HG: Hel Graben, JH: Jennegga High, LB: Lofoten Basin, LR: Lofoten Ridge, MMH: Møre Marginal High, NB: Norway Basin, NH: Nyk High,NS: Någrind Syncline, RB: Ribban Basin, RsB: Rås Basin, TrB: Trana Basin, TP: Trøndelag Platform, UH: Utgard High, UR: Utrøst Ridge, VB: Vestfjorden Basin, VE: Vøring Escarpment, VH: Vigra High, VMH: Vøring Marginal High, VS: Vigrid Syncline. 
dipping reflector (SDR) sequences (Mjelde et al., 2005b). Landward of the COT, seismic velocities of $\sim 6.0 \mathrm{~km} / \mathrm{s}$ in the top of the main crustal layer are conformable with granitic basement, whereas corresponding velocities seaward of the COT $(\sim 6.9 \mathrm{~km} / \mathrm{s})$ indicate gabbroic, oceanic crust. The COT is characterized by intermediate, $\sim 6.5 \mathrm{~km} / \mathrm{s}$, velocities, interpreted as heavily intruded continental crust that is underlain by a high-velocity LCB (Figure 3 ).

The Bivrost Lineament separates the Vøring and Lofoten-Vesterålen margins, marking the northern termination of the Vøring Plateau and the Vøring Marginal High, as well as the Vøring Escarpment (Figure 2) (e.g., Olesen et al., 2002). The Bivrost transfer zone is a major boundary in terms of margin physiography, structure, breakup magmatism, and lithosphere stretching; breakup-related magmatism is more voluminous south of it and the less magmatic Lofoten-Vesterålen margin was more susceptible to initial post-opening subsidence (Tsikalas et al., 2005b).

The Lofoten-Vesterålen margin is characterized by a narrow shelf and steep slope (Figure 1). The sedimentary basins underneath the shelf are narrower and shallower than on the Vøring and Møre margins (Figure 3, profiles 5-6). Typically they form asymmetric half-graben structures with changes in polarity bounded by a series of basement highs along the shelf edge. Beneath the slope, breakup-related lavas mask a sedimentary basin whose detailed mapping is hampered by poor seismic imaging (Tsikalas et al., 2001) Deep seismic profiles show $\sim 30 \mathrm{~km}$ Moho depth in the coastal areas and a distinct thinning beneath the Lofoten Islands (Figure 3; profiles 5 and 6 ). The latter has been related to the development of a core complex in the middle to lower crust in the Lofoten Islands region, which has been exhumed along detachments during large-scale extension (e.g., Mjelde et al., 1993; Steltenpohl et al., 2004; Tsikalas et al., 2005b). The continental crust on the Lofoten-Vesterålen margin appears to have experienced only moderate prebreakup extension, contrasting the greatly extended crust in the Vøring Basin farther south (Figure 3).

\section{Western Barents Sea-Svalbard margin}

Late Cretaceous-Paleocene rifting and subsequent breakup and initial seafloor spreading in the NorwegianGreenland Sea was linked to the Arctic Eurasia Basin by the regional De Geer Zone megashear system. The western Barents Sea-Svalbard margin developed along this zone and is composed of two large shear segments and a central rifted margin segment SW of Bjørnøya associated with volcanism (Figure 2). Each segment is characterized by distinct crustal properties, structural and magmatic styles, and history of vertical motion (Figure 4), mainly as a result of three controlling parameters (Faleide et al., 1991): (1) the pre-breakup structure, (2) the geometry of the plate boundary at opening and (3) the direction of relative plate motion. The COT is confined within a narrow zone $(10-20 \mathrm{~km})$ along the sheared margin segments (Breivik et al., 1999), but is more obscure and partly masked by volcanics at the rifted margin segments.

The Senja Fracture Zone (SFZ), or Senja Shear Margin, marks the southern segment of the predominantly sheared margin along the western Barents Sea (Figure 2). Landward of the SFZ, the margin bounds a basinal province in which as much as $18-20 \mathrm{~km}$ of sedimentary strata cover a highly attenuated crystalline crust (Figure 4; profile 7).

The Vestbakken Volcanic Province (VVP) is located at a rifted margin segment southwest of Bjørnøya, linking sheared margin segments to the south and north (Figure 2). An east-stepping of the Eocene dextral shear margin (releasing bend) gave rise to basin formation in a pull-apart setting. The VVP structures are mainly extensional, but transpres-
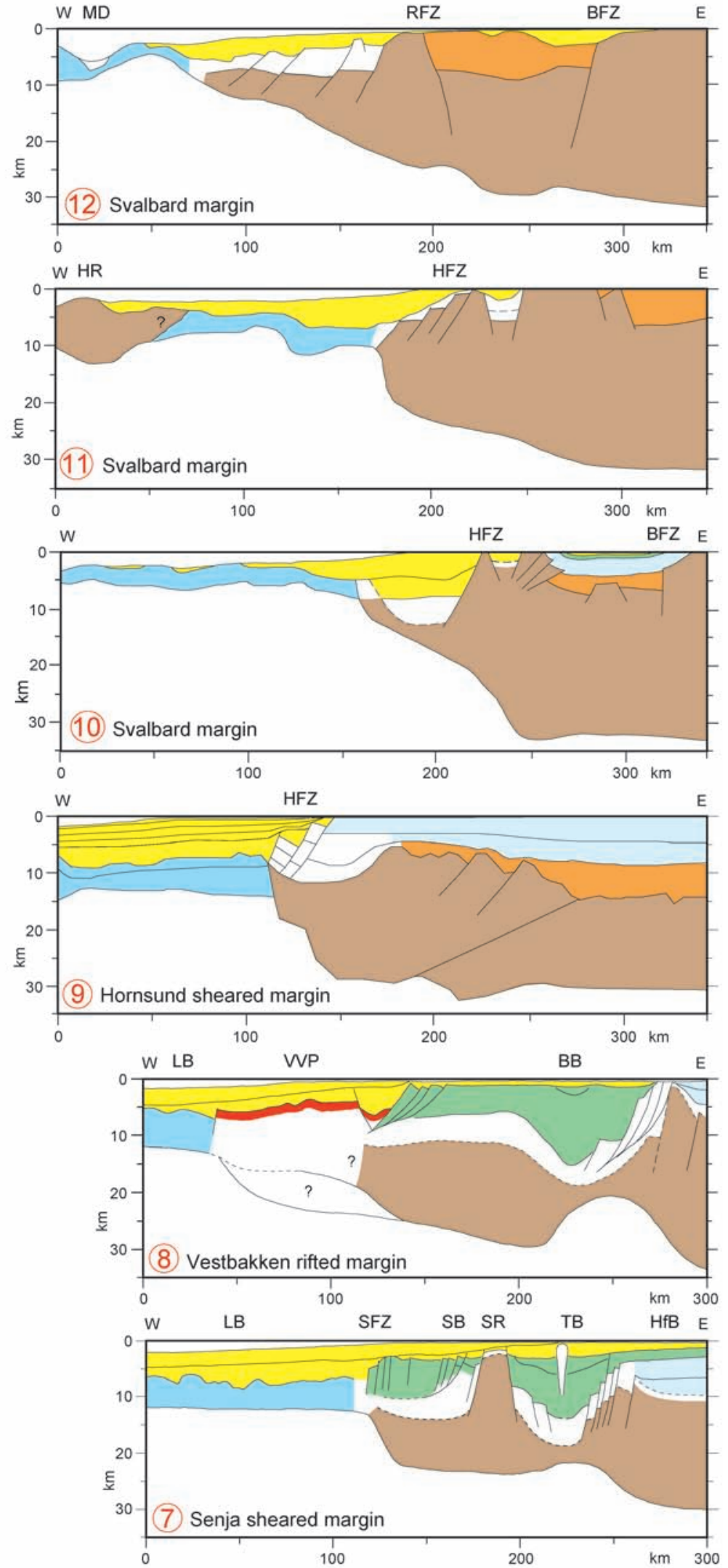

Figure 4 Crustal transects across the mainly sheared western Barents Sea-Svalbard margin. Location of profiles in Figure 2. For references see text. BB: Bjørnøya Basin, BFZ: Billefjorden Fault Zone, HfB: Hammerfest Basin, HFZ: Hornsund Fault Zone, HR: Hovgård Ridge, LB: Lofoten Basin, MD: Molloy Deep, RFZ: Raudfjorden Fault Zone, SB: Sørvestsnaget Basin, SFZ: Senja Fracture Zone, SR: Senja Ridge, TB: Tromsø Basin, VVP: Vestbakken Volcanic Province. 
sional structures are observed locally. Prominent volcanoes as well as sill intrusions are observed at the outer margin (Faleide et al., 1988). Repeated tectonic activity in a pull-apart setting within the Vestbakken Volcanic Province reflects that the Cenozoic evolution of the NE Norwegian-Greenland Sea was complex, and as much as eight tectonic and three volcanic events have been identified (Jebsen and Faleide, 1998).

The continental margin north of Bjørnøya can be further subdivided into three segments (Figure 2): (1) a sheared margin from Bjørnøya to Sørkapp at the southern tip of Spitsbergen $\left(74^{\circ} 30^{\prime}-76^{\circ} \mathrm{N}\right),(2)$ an initially sheared and later rifted margin west of Svalbard between Sørkapp and Kongsfjorden $\left(76-79^{\circ} \mathrm{N}\right)$, and (3) a complex sheared and rifted margin along NW Svalbard and SW Yermak Plateau associated with volcanism $\left(79-81^{\circ} \mathrm{N}\right)$. The crustal thickness changes abruptly from continental crust more than $30 \mathrm{~km}$ thick on the Svalbard Platform, including the Svalbard archipelago, to oceanic crust 2-6 km thick in the Greenland Sea (Figure 4; profiles 9-12).

The continental margin between Bjørnøya and Sørkapp shows a narrow zone of crustal thinning dominated by two large rotated downfaulted blocks with throws of 2-3 km on each fault (Figure 4; profile 9), formed during the transform margin development (Breivik et al., 2003). The down-faulted terrace at the margin shows signs of periodic minor compression or wrench-tectonism (Grogan et al., 1999; Bergh and Grogan, 2003).

The Spitsbergen Fold-and-Thrust Belt formed between a restraining (SW of Sørkapp) and releasing (NW of Kongsfjorden) bend when Greenland slid past Svalbard during latest Paleocene and Eocene times (Figure 5) (e.g., Bergh et al., 1997; Braathen et al., 1999) (Figure 4; profile 10). West of the fold-and-thrust belt the continental crust thins rapidly across the Svalbard margin (Figures 2 and 4) (Ritzmann et al., 2002; 2004). The Hovgård Ridge probably represents a microcontinent rifted off from the Barents SeaSvalbard margin (Figure 4; Profile 11) (Ritzmann et al., 2004). N-S trending grabens, up to $30 \mathrm{~km}$ wide, are present along the coast of NW Spitsbergen and SW Yermak Plateau (Figures 2 and 4). Profile 12 (Figure 4) shows a wider region of thin continental crust and a COT close to the present plate boundary at the Molloy Ridge (Ritzmann, 2003).

\section{East Greenland margin}

Opposite of the Norwegian margin, the conjugate Greenland margin has a narrow continental shelf in the south that becomes progressively wider northward (Figures 1 and 2). Integrated geophysical and geological studies have revealed pronounced differences in the crustal architecture of the East Greenland margin north and south of $72^{\circ} \mathrm{N}$ coinciding approximately with the landward prolongation of the West Jan Mayen Fracture Zone (WJMFZ) (e.g., Schlindwein and Jokat, 1999; Schmidt-Aursch and Jokat, 2005; Voss and Jokat, 2007). A lower crustal high-velocity body, interpreted as breakup-related magmatic underplating, is wider (190-225 km) and thicker (15-16 $\mathrm{km}$ ) than previously thought (Voss and Jokat, 2007). Compared to the mid-Norwegian margin the dimensions of the LCB are considerably

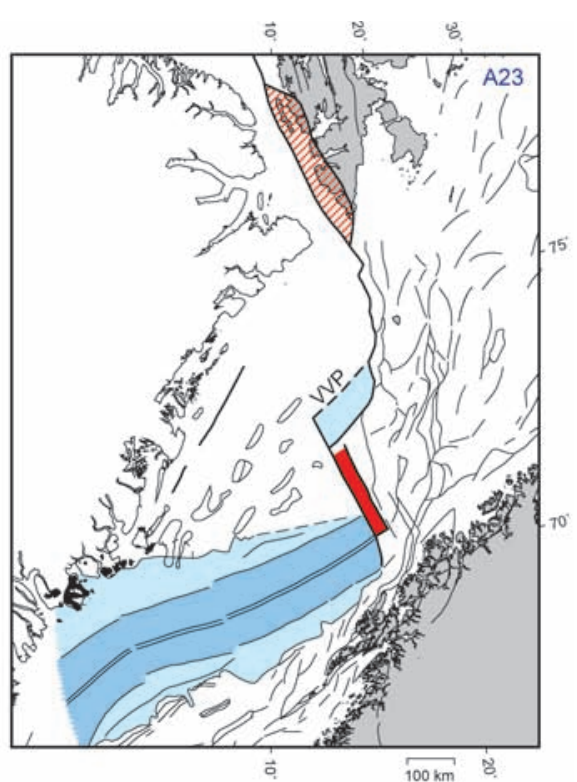

०
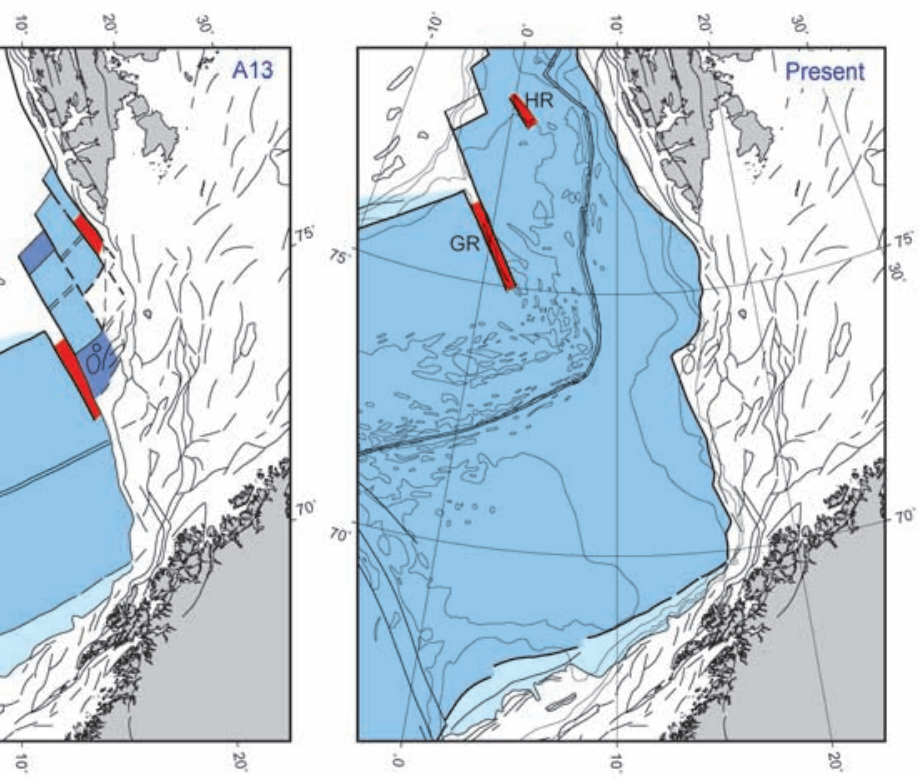

$\overrightarrow{0}$

ํ.

$\overrightarrow{0}$

Figure 5 Cenozoic plate tectonic evolution of the Norwegian-Greenland Sea. Figure 5 Cenozoic plate tectonic evolution of the Norwegian-Greenland
GR: Greenland Ridge, HR: Hovgård Ridge, VVP: Vestbakken Volcanic Basin.

larger on the Greenland side contributing to a significant asymmetry in crustal architecture between the two conjugate margins.

The fairly good definition of early seafloor spreading anomalies and the continent-ocean boundary (COB) along parts of the NE Greenland margin (Figure 2) is deteriorated in character and definition towards the south, where the seafloor spreading anomalies trend obliquely with respect to the continental slope and there are alternative views to the COB/COT location (e.g., Scott, 2000; Tsikalas et al., 2002; Voss and Jokat, 2007).

Off NE Greenland, a series of prominent, elongate N to NNEtrending highs and basins (Figure 2) are recognized on the seismic data and are outlined on the gravity and magnetic anomaly fields (Hamann et al., 2005; Tsikalas et al., 2005a). Several of the basins appear locally to be very deep although extensive sill intrusions make it difficult to image the deep basin configuration. These basins correspond to the deep Mesozoic basins on the mid-Norwegian margin and in the SW Barents Sea (Figures 2 and 5). 


\section{Margin evolution}

The conjugate NW European and East Greenland margins have a prolonged history of intermittent extension and basin formation, from post-Caledonian orogenic backsliding and collapse in Devonian times, to post-Early Eocene passive margin development governed by the widening and deepening of the NE Atlantic.

\section{Pre-breakup basin evolution}

The pre-opening, structural margin framework is dominated by the NE Atlantic-Arctic Late Jurassic-Early Cretaceous rift episode responsible for the development of major Cretaceous basins such as the Møre and Vøring basins off mid-Norway, and the deep basins in the SW Barents Sea (Figures 2-4). Prior to that, Late Paleozoic rift basins formed between Norway and Greenland and in the western Barents Sea along the NE-SW Caledonian trend (Figure 2).

It has been suggested that the main Late Paleozoic-early Mesozoic rift episodes took place in mid-Carboniferous, Carboniferous-Permian and Permian-Early Triassic times (Doré, 1991). Sediment packages associated with these movements are poorly resolved, mainly because of overprint by younger tectonism and burial by thick sedimentary strata. Carboniferous rift structures are widespread in the western Barents Sea (Gudlaugsson et al., 1998) (Figure 2) below an Upper Carboniferous-Lower Permian carbonate platform, which covered large areas of the present-day Arctic continental blocks. Thick evaporites were deposited in the Late Paleozoic rift basins on the SW Barents Sea margin, and off NE Greenland.

On the mid-Norwegian margin, the Trøndelag Platform (Froan Basin) and Vestfjorden Basin (Figure 3) record significant fault activity in Permian-Early Triassic time (Brekke, 2000; Osmundsen et al., 2002). Permian-Triassic extension is generally poorly dated, but is best constrained onshore East Greenland where a major phase of normal faulting culminated in the mid-Permian and further block faulting took place in the Early Triassic (e.g., Surlyk, 1990). The later Triassic basin evolution was characterized by regional subsidence and deposition of large sediment volumes. The Lower-Middle Jurassic strata (mainly sandstones) reflect shallow marine deposition prior to the onset of the next major rift phase.

A shift in the extensional stress field vector to NW-SE is recorded by the prominent NE Atlantic-Arctic late Middle Jurassicearliest Cretaceous rift episode, an event associated with northward propagation of Atlantic rifting (Faleide et al., 1993). Considerable crustal extension and thinning led to the development of major Cretaceous basins off mid-Norway (Møre and Vøring basins, Figures 2 and 3) and East Greenland, and in the SW Barents Sea (Harstad, Troms $\varnothing$, Bjørnøya and Sørvestsnaget basins, Figures 2 and 4). These basins underwent rapid differential subsidence and segmentation into sub-basins and highs.

In the North Atlantic realm, there is evidence for modest midCretaceous extension in the Vøring Basin (Doré et al., 1999), Lofoten-Vesterålen margin (Tsikalas et al., 2001), onshore East Greenland (Whitham et al., 1999), and SW Barents Sea (Faleide et al., 1993). However, Skogseid et al. (2000) and Færseth and Lien (2002) argued that no distinct structures of this age are identified within the Vøring Basin. Biostratigraphic data from the Vøring margin reveal a change from neritic to bathyal conditions and an increase in sediment accommodation space in the Aptian-Albian, attributed to eustatic sea-level rise and regional tectonism (Gradstein et al., 1999). Aptian rifting is well constrained in the SW Barents Sea (Faleide et al., 1993). Farther north, there are few signs of Cretaceous extensional deformation, but magmatism of Barremian-Aptian age is widespread within an Arctic large igneous province (LIP) (Grogan et al., 1998; Maher, 2001). Regional uplift in the north gave rise to southward sediment progradation in the Barents Sea.

By mid-Cretaceous time, most of the structural relief within the Møre and Vøring basins had been filled in and thick Upper Cretaceous strata, mainly fine-grained clastics were deposited in wide basins. Pulses of coarse clastic input with an East Greenland provenance appeared in the Vøring Basin from Early Cenomanian to at least Early Campanian times (Færseth and Lien, 2002).

\section{Breakup-related tectonism and magmatism}

Breakup in the NE Atlantic was preceded by prominent Late Cretaceous-Paleocene rifting. At the onset of this rifting, the area between NW Europe and Greenland was an epicontinental sea covering a region in which the crust had been extensively weakened by previous rift episodes. Ren et al. (2003) suggested onset of rifting at about $81 \mathrm{Ma}$ and that the main period of brittle faulting occurred in Campanian time followed by smaller-scale activity towards breakup. The Campanian rifting resulted in low-angle detachment structures that updome thick Cretaceous sequences and sole out at medium-todeep intra-crustal levels on the Vøring and Lofoten-Vesterålen margins (Tsikalas et al., 2001; Gernigon et al., 2003; Ren et al., 2003).

Late Cretaceous-Paleocene rifting at the Vøring Margin covers a $\sim 150 \mathrm{~km}$ wide area bounded by the Fles Fault Complex and the Utgard High on the east (Figures 2 and 3). Along the outer Møre and Lofoten-Vesterålen margins, most of the Late Cretaceous-Paleocene deformation is masked by the lavas, but the structures appears to continue seawards underneath the breakup lavas. On the Møre and Vøring margins, the Paleocene epoch was characterized by relatively deep water conditions. Depocentres in the western Møre and Vøring basins were sourced from the uplifted rift zone in the west (Hjelstuen et al., 1999). The northwestern corner of southern Norway was also uplifted and eroded, and the sediments were mainly deposited in the NE North Sea and SE Møre Basin (Martinsen et al., 1999; Faleide et al., 2002).

The Late Cretaceous-Paleocene extension between Norway and Greenland was taken up by strike-slip movements/deformation within the De Geer Zone (Figure 5). Pull-apart basins formed in the SW Barents Sea (e.g., Faleide et al., 1993; Breivik et al., 1998; Ryseth et al., 2003) and in the Wandel Sea Basin in NE Greenland (Håkansson and Pedersen, 2001). A relatively complete Paleocene succession was deposited under deep marine conditions in the Sørvestsnaget Basin and Vestbakken Volcanic Province (Ryseth et al., 2003).

Final lithospheric breakup at the Norwegian margin occurred near the Paleocene-Eocene transition at $~ 55-54 \mathrm{Ma}$ (Chron 24r). It culminated in a 3-6 m.y. period of massive magmatic activity during breakup and onset of early sea-floor spreading. At the outer margin (e.g., Møre and Vøring margins), the lavas form characteristic SDR sequences that drilling has demonstrated to be subaerially and/or neritically erupted basalts (Eldholm et al., 1989; Planke et al., 1999). These seaward dipping reflectors have become diagnostic features of volcanic margins. During the main igneous episode at the Paleocene-Eocene transition, sills intruded into the thick Cretaceous successions throughout the NE Atlantic margin, including the Vøring and Møre basins. Magma intrusion into organic-rich sedimentary rocks led to formation of large volumes of greenhouse gases that were vented to the atmosphere in explosive gas eruptions forming several thousand hydrothermal vent complexes along the Norwegian margin (Svensen et al., 2004; Planke et al., 2005).

The evolution of the western Barents Sea-Svalbard margin was more complex due to the sheared margin setting. The SW Barents Sea margin, along the Senja Fracture Zone (Figures 2 and 5), developed during the Eocene opening of the Norwegian-Greenland Sea, first by continent-continent shear followed by continent-ocean shear, and has been passive since earliest Oligocene time. Deep marine conditions persisted in the SW Barents Sea (Sørvestsnaget Basin) throughout Eocene time, with deposition of significant sandy submarine fans during the Middle Eocene (Ryseth et al., 2003). Breakup-related magmatism in the Vestbakken Volcanic Province was followed by down-faulting and deposition of thick Eocene strata (Figures 2 and 4; profile 8).

The Bjørnøya-Spitsbergen margin segment experienced oblique continent-continent and partly continent-ocean shear with 
both transtensional and transpressional components during Eocene time (Grogan et al., 1999; Bergh and Grogan, 2003). On Spitsbergen, a foreland basin was sourced from uplifted parts of the fold-andthrust belt in the west during latest Paleocene-Eocene times (Figure 4; profile 10) (Steel et al., 1985; Mueller and Spielhagen, 1990). At the end of Eocene, sea floor spreading had reached the margin off southern Spitsbergen and a narrow oceanic basin existed between the western Barents Sea and NE Greenland continental margins (Figure 5).

After a plate tectonic reorganization in earliest Oligocene time, Greenland (and North America) moved in a more westerly direction with respect to Eurasia (Figure 5). Significant marine shallowing took place at the Eocene-Oligocene transition in the Sørvestsnaget Basin (Ryseth et al., 2003). Early Oligocene rifting, related to the change in relative plate motion, reactivated faults in the Vestbakken Volcanic Province, in particular those with a NE-SW trend. This phase was also associated with renewed volcanism partly overprinting the breakup structures (Jebsen and Faleide, 1998). Transpressional movements west of Svalbard were replaced by oblique rifting and incipient seafloor spreading when relative plate motions changed in the earliest Oligocene, and narrow grabens developed along the Svalbard margin. The formation of these grabens was probably initiated within the Eocene wrench regime as indicated by minor compression observed in the deeper parts of the grabens (Gabrielsen et al., 1992; Kleinspehn and Teysser, 1992).

\section{Post-breakup margin evolution}

The mid-Norwegian margin experienced regional subsidence and modest sedimentation since Middle Eocene time and developed into a passive rifted margin bordering the oceanic NorwegianGreenland Sea. The mainly sheared western Barents Sea-Svalbard margin had a more complex development and the different segments reached the passive margin stage at different times (see previous section).

Mid-Cenozoic compressional deformation (including domes/ anticlines, reverse faults, and broad-scale inversion) is well documented on the Vøring margin, but its timing and significance are highly debated (Doré and Lundin, 1996; Vågnes et al., 1998; Lundin and Doré, 2002; Løseth and Henriksen, 2005; Stoker et al., 2005a). The main phase of deformation is clearly Miocene in age but some of the structures were probably initiated earlier in Late EoceneOligocene times.

The Miocene succession preserves a record of deep-water sedimentation that indicates an expansion of contourite sediment drifts (Eiken and Hinz, 1993; Laberg et al., 2005; Stoker et al., 2005b). Plate tectonic reconstructions indicate that the Fram Strait finally opened as a North Atlantic-Arctic Gateway in the Miocene (between 20 and $10 \mathrm{Ma}$; Engen et al., 2008) having major impact on ocean circulation. Deep water exchange was also enhanced through a southern gateway (the Faroe Conduit) and the general subsidence of the Greenland-Scotland Ridge (Stoker et al., 2005b).

There is increasing evidence on the Norwegian margin for Late Miocene outbuilding on the inner shelf (Molo Formation; Eidvin et al., 2007) indicating a regional, moderate uplift of Fennoscandia. At the western Barents Sea margin, a Late Miocene uplift event increases in amplitude eastwards within the Vestbakken Volcanic Province and may be related to pre-glacial tectonic uplift of the Barents Shelf (Jebsen and Faleide, 1998).

Over the entire shelf there is a distinct unconformity, which changes on the slope to a downlap surface for huge prograding wedges of sandy/silty muds sourced on the mainland areas around the NE Atlantic and the shelf (e.g., Barents Sea). This horizon marks the transition to glacial sediment deposition during the Northern Hemisphere Glaciation since about 2.6 Ma. Pliocene sedimentation is interspersed with ice-rafted debris signifying regional cooling and formation of glaciers. Large Plio-Pleistocene depocenters formed fans in front of bathymetric throughs scoured by ice streams eroding the shelf (Faleide et al., 1996; Laberg and Vorren, 1996; Dahlgren et al., 2005; Nygård et al., 2005; Rise et al., 2005). Plio-Pleistocene uplift and glacial erosion of the Barents Shelf and deposition of large volumes of glacial deposits in submarine fans along the margin resulted in a regional tilt of the margin (Dimakis et al., 1998). In terms of post-opening sediments, the glacial component constitutes more than half of the total volume deposited on the mid-Norwegian and western Barents Sea margins. The greatly enhanced Plio-Pleistocene deposition rates within the fans induced excess pore pressure and sediment instability resulting in a series of submarine slides of various sizes and timing (Bryn et al., 2005; Evans et al., 2005; Solheim et al., 2005; Hjelstuen et al., 2007).

\section{Concluding remarks}

The continental margin off mainland Norway and western Barents Sea-Svalbard, $62-82^{\circ} \mathrm{N}$, evolved in response to the Cenozoic opening of the Norwegian-Greenland Sea as a mainly rifted and sheared margin, respectively. The margins exhibit a distinct along-margin segmentation reflecting structural inheritance extending back to a complex pre-breakup geological history. The lithospheric breakup was accompanied by massive, regional magmatism within the North Atlantic Volcanic Province. The breakup was preceded by a rift episode, clearly recognized by low-angle normal faulting on the outer margin during the Campanian. The fault activity continued toward breakup but appears to have been less frequent during the Paleocene. This is ascribed to focussing toward the incipient plate boundary, an area now covered by lavas, as well as to a more ductile lithospheric response when the thermal regime changed. After breakup, the passive margin evolved in response to subsidence and sediment loading during the widening and deepening of the Norwegian-Greenland Sea. Sedimentation was modest until the Late Pliocene when the Northern Hemisphere Glaciation led to rapid progradation and greatly increased sedimentation rates forming huge, regional depocentres near the shelf edge offshore Mid-Norway and in front of bathymetric troughs in the northern North Sea and western Barents Sea.

\section{Acknowledgements}

Most of the recent work on the mid-Norwegian margin was carried out within the ESF EUROMARGINS program and funded by the Norwegian Research Council. We also acknowledge the contributions by AWI (Alfred Wegener Institute, Bremerhaven, Germany) on the Svalbard and East Greenland margins.

\section{References}

Bergh, S.G. and Grogan, P., 2003, Tertiary structure of the Sorkapp-Hornsund region, south Spitsbergen, and implications for the offshore southern extension of the fold-thrust belt: Norsk Geologisk Tidsskrift, v. 83 , pp. 43-60.

Bergh, S.G., Braathen, A., and Andresen, A., 1997, Interaction of basement-involved and thin-skinned tectonism in the Tertiary fold-thrust belt of central Spitsbergen, Svalbard: AAPG Bulletin, v. 81, pp. $637-661$.

Braathen, A., Bergh, S.-G., and Maher, H.D. Jr., 1999, Application of a critical wedge taper model to the Tertiary transpressional fold-thrust belt on Spitsbergen, Svalbard: Geological Society of America Bulletin, v. 111 , pp. 1468-1485.

Breivik, A.J., Faleide, J.I., and Gudlaugsson, S.T., 1998, Southwestern Barents Sea margin: late Mesozoic sedimentary basins and crustal extension: Tectonophysics, v. 293, pp. 21-44.

Breivik, A.J., Verhoef, J., and Faleide, J.I., 1999, Effect of thermal contrasts on gravity modeling at passive margins: results from the western Barents Sea: Journal of Geophysical Research, v. 104, pp. 15293-15312.

Breivik, A.J., Mjelde, R., Grogan, P., Shimamura, H., Murai, Y., and Nishimura, Y., 2003, Crustal structure and transform margin develop- 
ment south of Svalbard based on ocean bottom seismometer data: Tectonophysics v. 369, pp. 37-70.

Breivik, A.J., Mjelde, R., Faleide, J.I., and Murai, Y., 2006, Rates of continental breakup magmatism and seafloor spreading in the Norway Basin-Iceland Plume interaction: Journal of Geophysical Research, v. 111, B07102.

Brekke, H., 2000, The tectonic evolution of the Norwegian Sea continental margin with emphasis on the Vøring and Møre basins: Geological Society, London, Special Publications, v. 136, pp. 327-378.

Bryn, P., Berg, K., Forsberg, C.F., Solheim, A. and Kvalstad, T.J., 2005, Explaining the Storegga Slide: Marine and Petroleum Geology, v. 22, pp. 11-19.

Dahlgren, K.I.T., Vorren, T.O., Stoker, M.S., Nielsen, T., Nygård, A., and Sejrup, H.P., 2005, Late Cenozoic prograding wedges on the NW European continental margin: their formation and relationship to tectonics and climate: Marine and Petroleum Geology, v. 22, pp. 1089-1110

Dimakis, P., Braathen, B.I., Faleide, J.I., Elverhøi, A., and Gudlaugsson, S.T., 1998, Cenozoic erosion and the preglacial uplift of the SvalbardBarents Sea Region: Tectonophysics, v. 300, pp. 311-327.

Doré, A.G., 1991, The structural foundation and evolution of Mesozoic seaways between Europe and the Arctic: Palaeogeograhy, Palaeoclimatology, Palaeoecology, v. 87, pp. 441-492.

Doré, A.G. and Lundin, E.R., 1996, Cenozoic compressional structures on the NE Atlantic margin: nature, origin and potential significance for hydrocarbon exploration: Petroleum Geoscience, v. 2, pp. 299-311.

Doré A.G., Lundin, E.R., Jensen, L.N., Birkeland, Ø., Eliassen, P.E., and Fichler, C., 1999, Principal tectonic events in the evolution of the northwest European Atlantic margin, in Fleet, A.J. and Boldy, S.A.R., eds., Petroleum Geology of Northwest Europe: Proceedings of the 5th Conference: Geological Society, London, pp. 41-61.

Eidvin, T., Bugge, T., and Smelror, M., 2007, The Molo Formation, deposited by coastal progradation on the inner Mid-Norwegian continental shelf, coeval with the Kai Formation to the west and the Utsira Formation in the North Sea: Norwegian Journal of Geology, v. 87, pp. $75-142$.

Eiken, O. and Hinz, K., 1993, Contourites in the Fram Strait: Sedimentary Geology, v. 82, pp. 15-32.

Eldholm, O., Thiede, J., and Taylor, E., 1989, Evolution of the Vøring volcanic margin, in Eldholm, O., Thiede, J., and Taylor, E., eds., Proceedings of the Ocean Drilling Program, Scientific Results, 104: College Station (Ocean Drilling Program), TX, 1033-1065.

Eldholm, O., Tsikalas, F., and Faleide, J.I., 2002, The continental margin off Norway $62-75^{\circ} \mathrm{N}$ : Palaeogene tectono-magmatic segmentation and sedimentation, in Jolley, D.W. and Bell, B.R., eds., The North Atlantic Igneous Province: stratigraphy, tectonics, volcanic and magmatic processes: Geological Society, London, Special Publications, v. 197, pp. 39-68.

Engen, Ø., Faleide, J.I., and Dyreng, T.K., 2008, Opening of the Fram Strait gateway: A review of plate tectonic constraints: Tectonophysics, doi:10.1016/j.tecto.2008.01.002

Evans, D., Harrison, Z., Shannon, P.M., Laberg, J.S., Nielsen, T., Ayers, S., Holmes, R., Hoult, R.J., Lindberg, B., Haflidason, H., Long, D., Kuijpers, A., Andersen, E.S., and Bryn, P., 2005, Palaeoslides and other mass failures of Pliocene to Pleistocene age along the Atlantic continental margin of NW Europe: Marine and Petroleum Geology, v. 22, pp. 1131-1148.

Faleide, J.I., Myhre, A.M., and Eldholm, O., 1988, Early Tertiary volcanism at the western Barents Sea margin, in Morton, A. and Parson, L.M., eds., Early Tertiary volcanism and the opening of the NE Atlantic: Geological Society Special Publications, v. 39, pp. 135-146.

Faleide, J.I., Gudlaugsson, S.T., Eldholm, O., Myhre, A.M., and Jackson, H.R., 1991, Deep seismic transects across the western Barents Sea continental margin: Tectonophysics, v. 189, pp. 73-89.

Faleide, J.I., Vågnes, E., and Gudlaugsson, S.T., 1993, Late MesozoicCenozoic evolution of the southwestern Barents Sea in a regional riftshear tectonic setting: Marine and Petroleum Geology, v. 10, pp. $186-214$.

Faleide, J.I., Solheim, A., Fiedler, A., Hjelstuen, B.O., Andersen, E.S., and Vanneste, K., 1996, Late Cenozoic evolution of the western Barents Sea Svalbard continental margin: Global and Planetary Change, v. 12, pp. 5374.

Faleide, J.I., Kyrkjebø, R., Kjennerud, T., Gabrielsen, R.H., Jordt, H., Fanavoll, S., and Bjerke, M.D., 2002, Tectonic impact on sedimentary processes during Cenozoic evolution of the northern North Sea and surrounding areas, in Doré, A.G. et al., eds., Exhumation of the North Atlantic Margin: Timing, Mechanisms and Implications for Petroleum
Exploration: Geological Society, London, Special Publications, v. 196, pp. 235-269.

Færseth, R.B. and Lien, T., 2002, Cretaceous evolution in the Norwegian Sea-a period characterized by tectonic quiescence: Marine and Petroleum Geology, v. 19, pp. 1005-1027.

Gabrielsen, R.H., Kløvjan, O.S., Haugsbø, H., Midbøe, P.S., Nøttvedt, A., Rasmussen, E., and Skott, P.H., 1992, A structural outline of Forlandssundet Graben, Prins Karls Forland, Svalbard, Norsk Geologisk Tidsskrift, v. 72, pp. 105-120.

Gernigon, L., Ringenbach, J.C., Planke, S., Le Gall, B., and Jonquet-Kolst $\varnothing$, H., 2003, Extension, crustal structure and magmatism at the outer Vøring Basin, Norwegian margin: Journal of the Geological Society, London, v. 160, pp. 197-208.

Gernigon, L., Ringenbach, J.C., Planke, S., and Le Gall, B., 2004, Deep structures and breakup along volcanic rifted margins: insights from integrated studies along the outer Vøring Basin (Norway): Marine and Petroleum Geology, v. 21, pp. 363-372.

Gradstein, F.M., Kaminski, M.A., and Agterberg, F.P., 1999, Biostratigraphy and paleoceanography of the Cretaceous seaway between Norway and Greenland: Earth Science Reviews, v. 46, pp. 27-98.

Grogan, P., Nyberg, K., Fotland, B., Myklebust, R., Dahlgren, S., and Riis, F., 1998, Cretaceous magmatism south and east of Svalbard; evidence from seismic reflection and magnetic data. Polarforschung, v. 68, pp. 25-34.

Grogan, P., Østvedt-Ghazi, A.M., Larssen, G.B., Fotland, B., Nyberg, K., Dahlgren, S., and Eidvin, T., 1999, Structural elements and petroleum geology of the Norwegian sector of the northern Barents Sea, in Fleet, A.J. and Boldy, S.A.R., eds., Petroleum geology of Northwest Europe; proceedings of the 5th conference: Geological Society London, pp. $247-259$.

Gudlaugsson, S.T., Faleide, J.I., Johansen, S.E., and Breivik, A.J., 1998, Late Paleozoic structural development of the south-western Barents Sea: Marine and Petroleum Geology, v. 15, pp. 73-102.

Hamann, N.E., Wittaker, R.C. and Stemmerik, L., 2005, Structural and geological development of the North-East Greenland Shelf, in Doré, A.G. and Vining, B.A., eds., Petroleum Geology: North-West Europe and Global Perspectives - Proceedings of the 6th Petroleum Geology Conference: Geological Society, London, pp. 887-902.

Hjelstuen, B.O., Eldholm, O., and Skogseid, J., 1999, Cenozoic evolution of the northern Vøring margin: Geological Society of America Bulletin, v. 111, pp. 1792-1807.

Hjelstuen, B.O., Eldholm, O., and Faleide, J.I., 2007, Recurrent Pleistocene mega-failures on the SW Barents Sea margin: Earth and Planetary Science Letters, v. 258, pp. 605-618.

Håkansson, E. and Pedersen, S.A.S., 2001, The Wandel Hav strike-slip mobile belt; a Mesozoic plate boundary in north Greenland. Bulletin of the Geological Society of Denmark, v. 48, pp. 149-158.

Jakobsson, M., Cherkis, N.Z., Woodward, J., Macnab, R., and Coakley, B., 2000, New grid of Arctic bathymetry aids scientists and mapmakers: Eos Transactions American Geophysical Union, 81, 89, 93, 96.

Jebsen, C. and Faleide, 1998, Tertiary rifting and magmatism at the western Barents Sea margin (Vestbakken volcanic province): III international conference on Arctic margins, ICAM III; abstracts; plenary lectures, talks and posters, pp. 92.

Kleinspehn, K.L. and Teysser, C., 1992, Tectonics of the Palaeogene Forlandsundet Basin, Spitsbergen: A preliminary report, Norsk Geologisk Tidsskrift, v. 72, pp. 93-104.

Laberg, J.S. and Vorren, T.O., 1996, The Middle and Late Pleistocene evolution of the Bear Island Trough Mouth Fan: Global and Planetary Change, v. 12, pp. 309-330.

Laberg, J.S., Stoker, M.S., Dahlgren, K.I.T., de Haas, H., Haflidason, H., Hjelstuen, B.O., Nielsen, T., Shannon, P.M., Vorren, T.O., van Weering, T.C.E., and Ceramicol, S., 2005, Cenozoic alongslope processes and sedimentation on the NW European Atlantic margin: Marine and Petroleum Geology, v. 22, pp. 1069-1088.

Lundin, E.R. and Doré, A.G., 2002, Mid-Cenozoic post-breakup deformation in the "passive" margins bordering the Norwegian-Greenland Sea: Marine and Petroleum Geology, v. 19, pp. 79-93.

Løseth, H. and Henriksen, S., 2005, A mid to Late Miocene compression phase along the Norwegian passive margin, in Doré, A.G. and Vining, B.A., eds., Petroleum Geology: North-West Europe and Global Perspectives-Proceedings of the 6th Petroleum Geology Conference: Geological Society, London, pp. 845-859.

Maher, H.D. Jr., 2001, Manifestations of Cretaceous High Arctic large igneous province in Svalbard: Journal of Geology, v. 109, pp. 91-104.

Martinsen, O.J., Bøen, F., Charnock, M.A., Mangerud, G., and Nøttvedt, A., 1999 , Cenozoic development of the Norwegian margin $60-64^{\circ} \mathrm{N}$ : 
sequences and sedimentary response to variable basin physiography and tectonic setting, in Fleet, A.J. and Boldy, S.A.R., eds., Petroleum geology of Northwest Europe; proceedings of the 5th conference: Geological Society London, pp. 293-304.

Mjelde, R., Sellevoll, M.A., Shimamura, H., Iwasaki, T., and Kanazawa, T., 1993, Crustal structure beneath Lofoten, N. Norway, from vertical incidence and wide-angle seismic data: Geophysical Journal International, v. 114, pp. 116-126.

Mjelde, R., Shimamura, H., Kanazawa, T., Kodaira, S., Raum, T., and Shiobara, H., 2003, Crustal lineaments, distribution of lower crustal intrusives and structural evolution of the Vøring Margin, NE Atlantic; new insight from wide-angle seismic models: Tectonophysics, v. 369, pp. 199-218.

Mjelde, R., Raum, T., Breivik, A., Shimamura, H., Murai, Y., Takanami, T., and Faleide, J.I., 2005a, Crustal structure of the Vøring Margin, NE Atlantic: a review of geological implications based on recent OBS data, in Doré, A.G. and Vining, B.A., eds., Petroleum Geology: NorthWest Europe and Global Perspectives - Proceedings of the 6th Petroleum Geology Conference: Geological Society, London, pp. 803-813.

Mjelde, R., Raum, T., Myhren, B., Shimamura, H., Murai, Y., Takanami, T., Karpuz, R., and Næss, U., 2005b, Continent-ocean transition on the Vøring Plateau, NE Atlantic, derived from densely sampled ocean bottom seismometer data: Journal of Geophysical Research, v. 110; B05101, doi:10.1029/2004JB003026.

Mueller, R.D. and Spielhagen, R.F., 1990, Evolution of the Central Tertiary Basin of Spitsbergen; towards a synthesis of sediment and plate tectonic history: Palaeogeography, Palaeoclimatology, Palaeoecology, v. 80 , pp. $153-172$.

Nygård, A., Sejrup, H.P., Haflidason, H. and Bryn, P., 2005, The glacial North Sea Fan, southern Norwegian Margin: architecture and evolution from the upper continental slope to the deep-sea basin: Marine and Petroleum Geology, v. 22, pp. 71-84.

Olafsson, I., Sundvor, E., Eldholm, O. and Grue, K., 1992, Crustal structure from analysis of Expanded Spread Profiles: Marine Geophysical Researches, v. 14, pp. 137-162.

Olesen, O., Lundin, E., Nordgulen, Ø., Osmundsen, P.T., Skilbrei, J.R., Smethurst, M.A., Solli, A., Bugge, T. and Fichler, C., 2002, Bridging the gap between the onshore and offshore geology in Nordland, northern Norway: Norwegian Journal of Geology, v. 82, pp. 243-262.

Osmundsen, P.T., Sommaruga, A., Skilbrei, J.R. and Olesen, O., 2002 Deep structure of the Mid Norway rifted margin: Norwegian Journal of Geology, v. 82, pp. 205-224.

Planke, S., Alvestad, E. and Eldholm, O., 1999, Seismic characteristics of basaltic extrusive and intrusive rocks: The Leading Edge, March 1999.

Planke, S., Rasmussen, T., Rey, S.S. and Myklebust, R., 2005, Seismic characteristics and distribution of volcanic intrusions and hydrothermal vent complexes in the Vøring and Møre basins, in Doré, A.G. and Vining, B.A., eds., Petroleum Geology: North-West Europe and Global Perspectives - Proceedings of the 6th Petroleum Geology Conference: Geological Society, London, pp. 833-844.

Raum, T., 2000, Crustal structure and evolution of the Faeroe, Møre and Vøring margins from wide-angle seismic and gravity data: Ph.D. dissertation, University of Bergen, Norway.

Ren, S., Faleide, J.I., Eldholm, O., Skogseid, J. and Gradstein, F., 2003, Late Cretaceous-Paleocene tectonic development of the NW Vøring Basin: Marine and Petroleum Geology, v. 20, pp. 177-206.

Rise, L., Ottesen, D., Berg, K. and Lundin, E., 2005, Large-scale development of the mid-Norwegian margin during the last 3 million years: Marine and Petroleum Geology, v. 22, pp. 33-44.

Ritzmann, O., 2003, Architecture and geodynamic evolution of the Svalbard Archipelago, the Yermak Plateau and the Fram Strait oceanic province, from deep seismic experiments. Reports on Polar Research, 439, Alfred Wegener Institute for Polar and Marine Research, Bremerhaven.

Ritzmann, O., Jokat, W., Mjelde, R. and Shimamura, H., 2002, Crustal structure between the Knipovich Ridge and the Van Mijenfjorden (Svalbard): Marine Geophysical Researches, v. 23, pp. 379-401.

Ritzmann, O., Jokat, W., Czuba, W., Guterch, A., Mjelde, R. and Nishimura, Y., 2004, A deep seismic transect from Hovgård Ridge to northwestern Svalbard across the continental-ocean transition: A sheared margin study: Geophysical Journal International, v. 157, pp. 683-702.

Ryseth, A., Augustson, J.H., Charnock, M., Haugerud, O., Knutsen, S.-M., Midbøe, P.S., Opsal, J.G. and Sundsbø, G., 2003, Cenozoic stratigraphy and evolution of the Sørvestsnaget Basin, southwestern Barents Sea: Norwegian Journal of Geology, v. 83, pp. 107-130.
Saunders, A.D., Fitton, J.G., Kerr, A.C., Norry, M.J., and Kent, R.W., 1997, The North Atlantic Igneous Province: Geophysical Monograph 100, American Geophysical Union, pp. 45-93.

Schlindwein, V. and Jokat, W., 1999, Structure and evolution of the continental crust of northern east Greenland from integrated geophysical studies: Journal of Geophysical Research, v. 104, pp. 15227-15245.

Schmidt-Aursch, M.C. and Jokat, W., 2005, The crustal structure of central East Greenland-I: From the Caledonian orogen to the Tertiary igneous province: Geophysical Journal International, v. 160, pp. 736-752.

Scott, R.A., 2000. Mesozoic-Cenozoic evolution of east Greenland: implications of a reinterpreted continent ocean boundary location, Polarforschung, v. 68, pp. 83-91.

Skogseid, J., Planke, S., Faleide, J.I., Pedersen, T., Eldholm, O., and Neverdal, F., 2000, NE Atlantic continental rifting and volcanic margin formation: Geological Society, London, Special Publications, v. 167, pp. 295-326.

Solheim, A., Berg, K., Forsberg, C.F., and Bryn, P., 2005, The Storegga Slide complex: repetitive large scale sliding with similar cause and development: Marine and Petroleum Geology, v. 22, pp. 97-107.

Steel, R., Gjelberg, J., Helland-Hansen, W., Kleinspehn, K., Nøttvedt, A. and Rye-Larsen, M., 1985, The Tertiary strike-slip basins and orogenic belt of Spitsbergen: Special Publication - Society of Economic Paleontologists and Mineralogists, v. 37, pp. 339-359.

Steltenpohl, M.G., Hames, W.E., and Andresen, A., 2004, The Silurian to Permian history of a metamorphic core complex, in Lofoten, northern Scandinavian Caledonides: Tectonics, v. 23, TC1002, doi:10.1029/ 2003 TC001522.

Stoker, M.S., Hoult, R.J., Nielsen, T., Hjelstuen, B.O., Laberg, J.S, Shannon, P.M., Praeg, D., Mathiesen, A., van Weering, T.C.E., and McDonnell, A., 2005a, Sedimentary and oceanographic responses to early Neogene compression on the NW European margin: Marine and Petroleum Geology, v. 22, pp. 1031-1044.

Stoker, M.S., Praeg, D., Hjelstuen, B.O., Laberg, J.S., Nielsen, T., and Shannon, P.M., 2005b, Neogene stratigraphy and the sedimentary and oceanographic development of the NW European Atlantic margin: Marine and Petroleum Geology, v. 22, pp. 977-1005.

Surlyk, F., 1990, Timing, style and sedimentary evolution of Late Paleozoic-Mesozoic extensional basins of East Greenland, in Hardman, R.P.F. and Brooks, J., eds., Tectonic events responsible for Britain's oil and gas reserves: Geological Society, London, Special Publications, v. 55, pp. 107-125.

Svensen, H., Planke, S., Malthe-Sørenssen, A., Jamtveit, B., Myklebust, R., Rasmussen, T., and Rey, S., 2004, Release of methane from a volcanic basin as a mechanism for initial Eocene global warming: Nature, v. 429, pp. 542-545.

Tsikalas, F., Faleide, J.I., and Eldholm, O., 2001, Lateral variations in tectono-magmatic style along the Lofoten-Vesterålen volcanic margin off Norway: Marine and Petroleum Geology, v. 18, pp. 807-832.

Tsikalas, F., Eldholm, O., and Faleide, J.I., 2002, Early Eocene sea floor spreading and continent-ocean boundary between Jan Mayen and Senja fracture zones in the Norwegian-Greenland Sea: Marine Geophysical Researches, v. 23, pp. 247-270.

Tsikalas, F., Faleide, J. I., Eldholm, O., and Wilson, J., 2005a, Late Mesozoic-Cenozoic structural and stratigraphic correlations between the conjugate mid-Norway and NE Greenland continental margins, in Doré, A.G. and Vining, B.A., eds., Petroleum Geology: North-West Europe and Global Perspectives-Proceedings of the 6th Petroleum Geology Conference: Geological Society, London, pp. 785-801.

Tsikalas, F., Eldholm, O., and Faleide, J.I., 2005b, Crustal structure of the Lofoten-Vesterålen continental margin, off Norway: Tectonophysics, v. 404, pp. 151-174.

Voss, M. and Jokat, W., 2007, Continent-ocean transition and voluminous magmatic underplating derived from $\mathrm{P}$-wave velocity modelling of the East Greenland continental margin: Geophysical Journal International, v. 170 , pp. 580-604.

Vågnes, E., Gabrielsen, R.H., and Haremo, P., 1998, Late CretaceousCenozoic intraplate contractional deformation at the Norwegian continental shelf: timing, magnitude and regional implications: Tectonophysics, v. 300, pp. 29-46.

Whitham, A.G., Price, S.P., Koraini, A.M., and Kelly, S.R.A., 1999, Cretaceous (post-Valanginian) sedimentation and rift events in NE Greenland (71-77 degrees N), in Fleet, A.J. and Boldy, S.A.R., eds., Petroleum Geology of Northwest Europe: Proceedings of the 5th Conference: Geological Society, London, pp. 325-336. 
Jan Inge Faleide is professor at Department of Geosciences, University of Oslo where he also achieved his cand.real. (1981) and dr.scient. (1990) degrees. He has been project leader/PI for several interdisciplinary and international research projects focussing on the formation and evolution of sedimentary basins and continental margins. Most studies have been located offshore Norway and carried out in close collaboration with the petroleum industry.

Filippos Tsikalas is currently working as Senior Explorationist in ENI Norge AS-on leave from his position as associate professor at Department of Geosciences, University of Oslo. He was awarded his cand.scient. and dr.scient. degrees from University of Oslo in 1992 and 1997, respectively. His main research interests comprise passive margin and marine geophysical studies, as well as impact craters.

Asbjørn Breivik is a researcher at Department of Geosciences, University of Oslo where he also achieved his cand.scient. (1991) and dr.scient. (1998) degrees. He has also worked as a postdoc at University of Bergen and had a short period consulting in the petroleum industry. His main research interests cover magmatic processes during continental breakup and seafloor spreading and basement architecture offshore Norway.
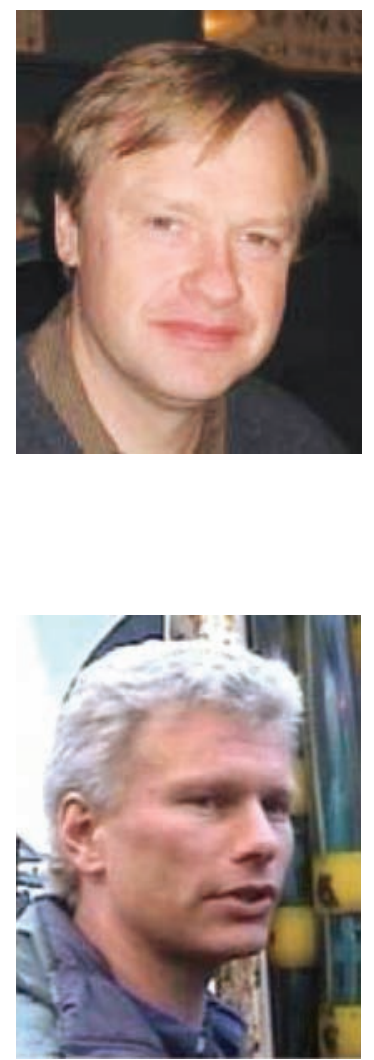
geophysics, plate tectonics and geo-
Jonas Wilson graduated from the University of Oslo in 2003 and continued to work there as a research assistant in two projects focusing on the Mid-Norwegian continental margin. He took part in the construction of some of the profiles shown in this paper based on an integrated analysis of seismic and gravity data. He is currently working with international exploration for StatoilHydro.

Oliver Ritzmann is a researcher at Department of Geosciences, University of Oslo. He received his PhD 2003 based on studies of the Svalbard margin carried out by the Alfred Wegener InstiAWI . In Oslo, he has mainly focused on the the deep structure and evolution of the Barents Sea region.

Øyvind Engen is a postdoc at Department of Geosciences, Univercan Oslo where he received his (2005) degrees. He has also had two research stays abroad at the universities of Hawaii and Oxford. His dynamics.

Olav Eldholm has been professor and head of Department of Earth Science, University of Bergen since 2003. Before that he had a long career at the University of Oslo (1976-2003). He was awarded his cand.real. (1967) and dr.philos. (1976) degrees from University of Bergen. His main research interests cover marine geophysics, structure and evolution of continental margins and Large Igneous Provinces. He has a long record of international collaboration in particular within the ODP/IODP programs.
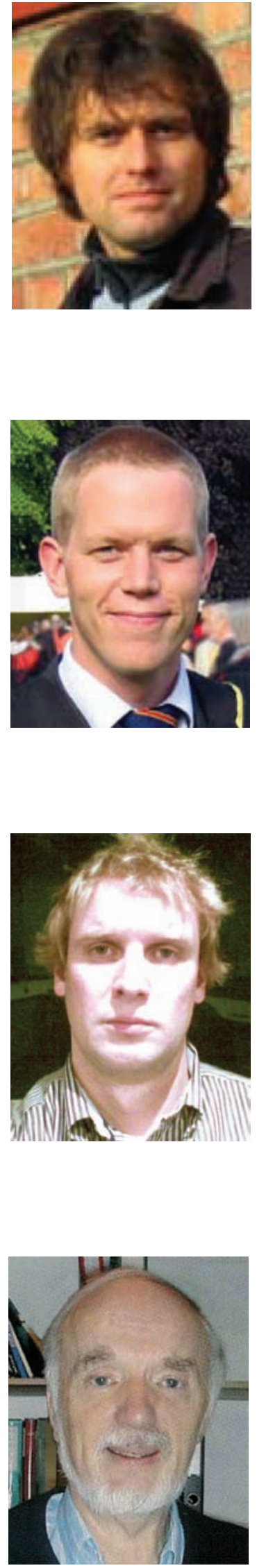